\title{
BRAZILIAN OFFSHORE WAVE CLIMATE BASED ON NWW3 REANALYSIS
}

\author{
Cássia Pianca ${ }^{1 *}$, Piero Luigi F. Mazzini ${ }^{2}$ and Eduardo Siegle ${ }^{1 * *}$ \\ ${ }^{1}$ Instituto Oceanográfico da Universidade de São Paulo \\ (Praça do Oceanográfico, 191, 05508-120 São Paulo, SP, Brasil) \\ *catitapianca@usp.br; **esiegle@usp.br \\ ${ }^{2}$ Oregon State University \\ PhD student - Physical Oceanography - College of Oceanic \& Atmospheric Sciences \\ (104 COAS Admin Bldg - Corvallis, OR 97331-5503 - Office: Burt 293 - United States) \\ pmazzini@coas.oregonstate.edu
}

\section{A B S T R ACT}

This paper provides a description of the wave climate off the Brazilian coast based on an eleven-year time series (Jan/1997-Dec/2007) obtained from the NWW3 operational model hindcast reanalysis. Information about wave climate in Brazilian waters is very scarce and mainly based on occasional short-term observations, the present analysis being the first covering such temporal and spatial scales. To define the wave climate, six sectors were defined and analyzed along the Brazilian shelf-break: South (W1), Southeast (W2), Central (W3), East (W4), Northeast (W5) and North (W6). W1, W2 and W3 wave regimes are determined by the South Atlantic High (SAH) and the passage of synoptic cold fronts; W4, W5 and W6 are controlled by the Intertropical Convergence Zone (ITCZ) and its meridional oscillation. The most energetic waves are from the $\mathrm{S}$, generated by the strong winds associated to the passage of cold fronts, which mainly affect the southern region. Wave power presents a decrease in energy levels from south to north, with its annual variation showing that the winter months are the most energetic in $\mathrm{W} 1$ to $\mathrm{W} 4$, while in $\mathrm{W} 5$ and $\mathrm{W} 6$ the most energetic conditions occur during the austral summer. The information presented here provides boundary conditions for studies related to coastal processes, fundamental for a better understanding of the Brazilian coastal zone.

\section{RESUMO}

O presente trabalho apresenta o clima de ondas da região ao largo da costa brasileira com base em uma série temporal de onze anos (Jan/1997-Dez/2007) obtida através de dados de reanálise do modelo operacional NWW3. Informações sobre o regime de ondas no Brasil são escassas e baseadas em observações ocasionais de curto período, sendo a presente análise inédita na escala espaçotemporal apresentada. Para a definição do clima de ondas foram definidos e analisados seis setores ao longo da quebra da plataforma continental brasileira: Sul (W1), Sudeste (W2), Central (W3), Leste (W4), Nordeste (W5) e Norte (W6). W1, W2 e W3 possuem os regimes de ondas controlados pela Alta Subtropical do Atlântico Sul (ASAS) e pela passagem de frentes frias sinóticas; W4, W5 e W6 são controlados pela Zona de Convergência Intertropical (ZCIT) e sua oscilação meridional. As ondas mais energéticas são de $\mathrm{S}$, geradas por ventos intensos associados à passagem de frentes frias, afetando principalmente a região sul e sudeste do país. A energia das ondas apresenta um decréscimo de sul para norte, com a sua variação anual mostrando que o período de inverno as ondas são mais energéticas nos setores W1 a W4, enquanto que nos setores W5 e W6 as condições mais energéticas ocorrem nos meses de verão do hemisfério sul. As informações aqui apresentadas fornecem condições de contorno para diferentes estudos relacionados a processos costeiros, fundamentais para a melhor compreensão da zona costeira do Brasil.

Descriptors: Sea state, waves, Brazilian Coast, WaveWatch III.

Descritores: Estado do mar, Ondas, costa brasileira, WaveWatch III.

\section{INTRODUCTION}

The offshore wave field defines the amount of wave-generated energy delivered to the coastal zone; its characterization is, therefore, of prime importance for the study of coastal processes. These waves are generated by winds that blow over the sea

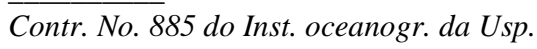

surface and their characteristics depend on the wind intensity, duration and fetch. As they leave the generation area they propagate at velocities that depend on their wave length, traveling long distances without significant energy dissipation. Wave energy dissipation in nearshore regions is the main driving force of the dynamics of coastal systems. Windgenerated high frequency gravity waves play a crucial role in the coastal zone since they dissipate energy at 
the coast, being responsible for controlling the morphological features of the coastline. When waves approach the coast and break on a sloping beach, they generate a variety of currents in the nearshore, determining the direction of the movement of beach sediments (KOMAR, 1998).

Additionally to the coastal morphodynamic processes, the knowledge of the wave climate of a region becomes increasingly important due to the use of coastal areas by humans. Being home for $70 \%$ of all human beings (CHERFAS, 1990), activities in coastal areas depend on the understanding of the regional forcing conditions.

The objective of this paper is to describe the general wave climate off the Brazilian coast thus providing boundary conditions for regional studies of wave-generated processes. In spite of their importance, wave measurements in Brazil are very scarce, and only a few studies assessed regional wave characteristics based on short-term observations (e.g.: CANDELLA, 1997; PEREIRA et al., 2000; ARAUUJO et al., 2003; BENSI et al., 2005). However, with the development of accurate ocean-atmosphere interaction models such as the NOAA WAVEWATCH-III - NWW3 (TOLMAN, 1999), it has become possible to obtain long term time series data from model hindcast.

This paper aims to present basic wind generated wave characteristics for the whole offshore region of Brazil, based on an eleven-year time series (Jan/1997-Dec/2007) of wave data extracted from the NWW3 operational wave model hindcast reanalysis. This analysis, on such temporal and spatial scale, provides new information on the wave climate of the Brazilian coast. Offshore wave data are very useful as boundary conditions for coastal wave models (e.g. SEBASTIÃO et al., 2000; SIEGLE et al., 2004; SIEGLE; ASP, 2007; SIEGLE et al., 2007; BITTENCOURT et al., 2007; RUSU et al., 2008). The frequency tables used in the analysis shown here will be made available at the Oceanographic Institute of the University of São Paulo (IO/USP) Coastal Dynamics Lab. website (http://ldc.io.usp.br/waves).

The NOAA WAVEWATCH-III model was developed at the National Center for Environmental Prediction (NCEP) of the National Oceanic and Atmospheric Administration (NOAA) of the United States of America (TOLMAN, 1999). The model solves the spectral action density balance equation for wave number-direction spectra. The growth, refraction, and decay of each component of the complete sea state, for each specific frequency and direction are solved, giving complete and realistic characteristics of the transient wave field. The physical processes included in the model are: refraction and straining of the wave field due to temporal and spatial variations of the mean water depth and of the mean current, wave growth and decay due to the actions of wind, nonlinear resonant interactions, dissipation by white-capping, and bottom friction. Further details of the WAVEWATCH-III model can be found in Tolman (1999).

The global model includes the entire globe as its domain, with a spatial resolution of $1^{\circ} \times 1.25^{\circ}$, in latitude and longitude respectively, with the grid ranging from $78^{\circ} \mathrm{N}$ to $78^{\circ} \mathrm{S}$, and uses wind fields and air-sea temperature differences as input. The NWW3 operational model has as input 3 hourly winds from the operational Global Data Assimilation Scheme (GDAS) and the aviation cycle of the Medium Range Forecast model (KANAMITSU, 1989; KANAMITSU et al., 1991; DERBER et al., 1991; CAPLAN et al., 1997), called now the Global Forecast System or GFS. Sea Surface Temperatures are also obtained from the GDAS, as they are needed in the stability correction for wave growth.

\section{Methods \\ Available Data}

The data used in this paper are available from the NOAA/NCEP wave generation model WAVEWATCH III (TOLMAN, 1997, 1999). These model runs based on the NCEP wind data reanalysis for an eleven-year period are used here to define the wave climate for the Brazilian coast. Significant wave height, period and direction, ranging from January/1997 to December/2007, were extracted from the NWW3 operational wave model hindcast reanalysis (archived), available for downloading at the internet website http://polar.ncep.noaa.gov/waves. The data are provided at 3-hour intervals, at $00: 00 \mathrm{~h}$, 03:00h, 06:00h, 09:00h, 12:00h, 15:00h, 18:00h and 21:00h every day. This dataset constitutes the basis of the analyses conducted in this paper.

\section{Coastal Sectors}

The Brazilian coastline has an extension of approximately $9,200 \mathrm{~km}$, presenting a very diverse suite of coastal environments (DOMINGUEZ, 2009). In order to define the wave climate acting on these varying environments, we defined six wave data extraction points off the Brazilian coast (Fig. 1). Central grid points based on the model grid $\left(1^{\circ}\right.$ latitude $\mathrm{x} 1.25^{\circ}$ longitude) have, therefore, been defined off each coastal sector close to the shelf break (at water depths greater than $200 \mathrm{~m}$ ), as follows:

- W1 $\left(32^{\circ} \mathrm{S}, 48.75^{\circ} \mathrm{W}\right)$ - Southern Sector;

- W2 $\left(26^{\circ} \mathrm{S}, 45^{\circ} \mathrm{W}\right)$ - Southeastern Sector;

- W3 $\left(19^{\circ} \mathrm{S}, 36.25^{\circ} \mathrm{W}\right)$ - Central Sector;

- W4 $\left(9^{\circ} \mathrm{S}, 33.75^{\circ} \mathrm{W}\right)$ - Eastern Sector;

- W5 $\left(3^{\circ} \mathrm{S}, 37.5^{\circ} \mathrm{W}\right)$ - Northeastern Sector;

- W6 $\left(2^{\circ} \mathrm{N}, 46.25^{\circ} \mathrm{W}\right)$ - Northern Sector. 


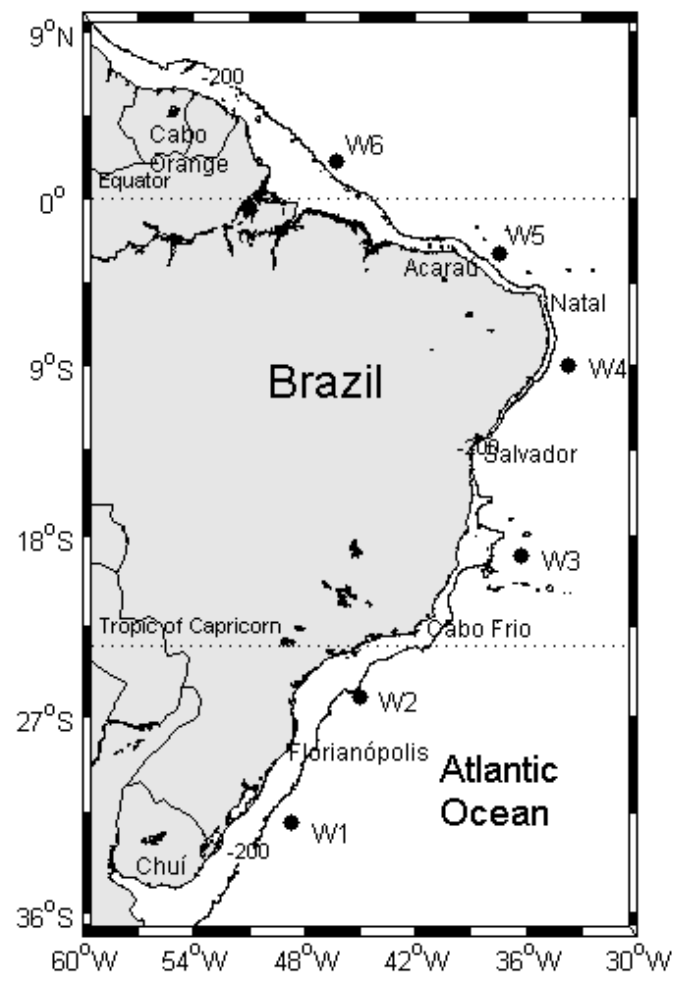

Fig. 1. Study area with the grid points used in the analysis. The 200-meter isobath indicates the shelf break.

\section{Data Validation}

Since only limited measured wave time series are available for the region of interest, we make a qualitative comparison of the data from the NWW3 hindcast reanalysis with the data measured by the LAHIMAR/UFSC off Florianópolis (Santa Catarina Island) and presented by Araújo et al. (2003). Data from the NWW3 was, therefore, extracted from the closest grid point to the waverider, at $28^{\circ} \mathrm{S} 47.5^{\circ} \mathrm{W}$ (Fig. 2). The period selected for comparison is that from December 2001 to January 2003, which is covered by the measured data.

\section{Data Analysis}

Wave climate may be defined as the set of prevailing wave conditions that reach a particular oceanic or coastal region over a defined time interval (INMAN; MASTERS, 1994). Therefore, based on the available dataset, the simple statistical analysis presented here aims to describe the general wave climate for each sector of the Brazilian coast. The wave climate is given based on seasonal directional histograms and basic statistics, such as minimum, maximum, mean, range, standard deviation and variance for the significant wave height and period. In the plotted wave roses, their bars point in the direction from which waves travel.

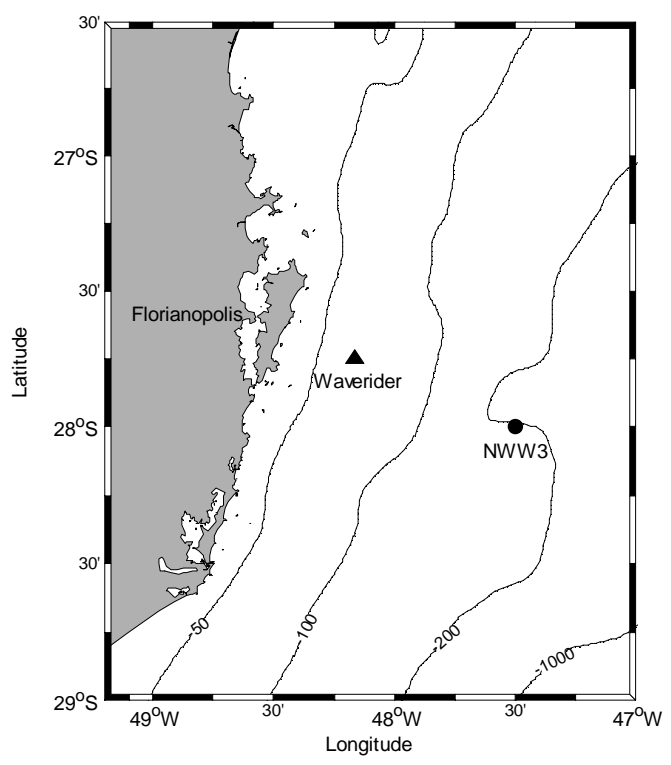

Fig. 2. Locations of the waverider buoy used by Araújo et al. (2003) and the NWW3 grid point used for model validation.

Further, in order to quantify the synergy of wave height and period in each sector, wave power $P$ was calculated by:

$P=\rho g^{2} H^{2} T / 32 \pi$

where $\rho$ is water density $\left(1,027 \mathrm{~kg} / \mathrm{m}^{3}\right), \mathrm{g}$ the acceleration due to gravity, $H$ the wave height (m) and $T$ the wave period (s). $\mathrm{P}$ is given in $\mathrm{W} / \mathrm{m}$.

\section{Results}

\section{Data Validation}

Hindcasts from global wave generation models such as NWW3 have been verified by comparing their outputs with measured data (e.g. WANG; SWAIL, 2001; GRAHAM; DIAZ, 2001; TOLMAN et al., 2002; CAIRES et al., 2004). These studies show that although some uncertainties are involved in the modeling process due to model limitations and wind data, they prove to be very useful for examining the wave climate and particular wave events. For example, Tolman et al. (2002) compared the NWW3 output with several buoy measurements and concluded that the model overestimates the wave heights by about $10 \%$.

Qualitative comparisons between seasonal waves characteristics, based on observations by Araújo et al. (2003) and NWW3 hindcast reanalysis, 
are presented in Figure 3. The overall comparison shows similar wave patterns for both the measured and modeled data. Comparing the seasonal wave climate, during summer the directions are very similar, with the main direction of incidence being from the south (42\% in the observations; $30 \%$ in the model). The model slightly overestimates the occurrence of higher waves $(3-4 \mathrm{~m})$ from the south. Easterly waves are well represented by the model, including the height classes. The occurrence of the northeasterly waves is overestimated by the modeled data. This might be a result of the distance between the more protected

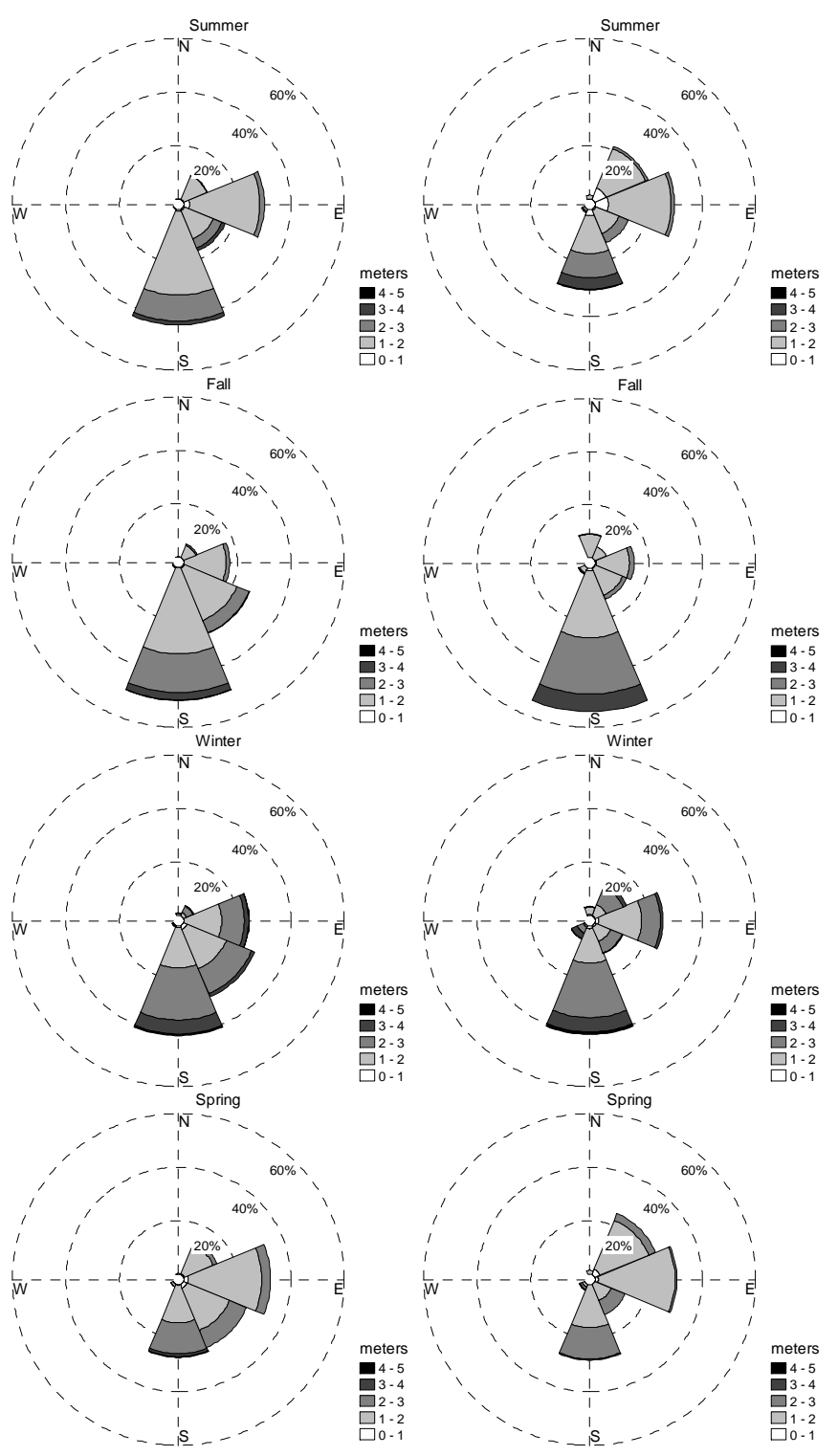

(inshore) measurement and the exposed grid node in the model (approximately $80 \mathrm{~km}$ offshore). Southeasterly waves are well represented by the model, with only small differences in wave heights. During fall months, with the exception of a modeled underestimation of the southeasterly waves, the overall wave climate is well represented by the model. During winter, the dominant southerly waves are well represented, with the main differences being related to the model's underestimation of the occurrence of southeasterly waves and its overestimation of that of northeasterly waves.
Fig. 3. Directional histograms of wave heights, comparing measured (left - ARAÚJO et al., 2003) and modeled (right- NWW3) data. 
These comparisons, although qualitative, show that the overall wave climate is well represented by the model for the year compared in one of the coastal sectors of the Brazilian coast. Thus, in the description of the results presented below, we assume that the modeled wave data are representative of the wave climate for the study area.

Brazilian Sectors

In this section we describe the results relating to the seasonal wave climate for each of the six coastal sectors defined above. Results are based on the percentage of wave occurrence for each season. Directional histograms of seasonal wave heights and periods for each sector are presented in Figures 4 to 9 , with Tables 1,2 and 3 presenting respectively the seasonal statistics of wave heights, periods and directions. Results are described in topics according to their seasonal statistics during the elevenyear period.

Table 1. Statistics of the seasonal wave heights for each point.

\begin{tabular}{ccccccc}
\hline \hline Season & Hmin & Hmax & range & mean & std & var \\
\hline W1-Fall & 0.6 & 7.4 & 6.8 & 2.4 & 1.1 & 1.0 \\
W2-Fall & 0.5 & 6.4 & 5.8 & 2.0 & 0.9 & 0.7 \\
W3-Fall & 0.7 & 4.4 & 3.7 & 2.0 & 0.7 & 0.4 \\
W4-Fall & 1.1 & 4.0 & 2.9 & 2.0 & 0.5 & 0.2 \\
W5-Fall & 0.9 & 2.8 & 1.9 & 1.8 & 0.4 & 0.1 \\
W6-Fall & 0.9 & 3.0 & 2.1 & 1.7 & 0.4 & 0.1 \\
\hline W1-Winter & 0.7 & 7.0 & 6.3 & 2.6 & 1.0 & 0.8 \\
W2-Winter & 0.5 & 5.8 & 5.3 & 2.2 & 0.8 & 0.6 \\
W3-Winter & 0.5 & 5.0 & 4.4 & 2.2 & 0.6 & 0.3 \\
W4-Winter & 0.9 & 4.3 & 3.4 & 2.2 & 0.5 & 0.2 \\
W5-Winter & 0.9 & 3.4 & 2.5 & 2.1 & 0.4 & 0.1 \\
W6-Winter & 0.7 & 2.6 & 1.9 & 1.6 & 0.3 & 0.1 \\
\hline W1-Spring & 0.7 & 5.9 & 5.2 & 2.2 & 0.8 & 0.6 \\
W2-Spring & 0.6 & 4.5 & 3.9 & 1.9 & 0.6 & 0.4 \\
W3-Spring & 0.7 & 4.0 & 3.3 & 1.7 & 0.5 & 0.2 \\
W4-Spring & 0.9 & 3.8 & 2.9 & 1.8 & 0.4 & 0.1 \\
W5-Spring & 0.8 & 3.2 & 2.4 & 2.0 & 0.4 & 0.1 \\
W6-Spring & 0.8 & 3.4 & 2.6 & 1.8 & 0.4 & 0.1 \\
\hline W1-Summer & 0.5 & 5.9 & 5.4 & 2.0 & 0.8 & 0.5 \\
W2-Summer & 0.7 & 4.0 & 3.4 & 1.7 & 0.7 & 0.3 \\
W3-Summer & 0.7 & 4.3 & 3.6 & 1.6 & 0.6 & 0.2 \\
W4-Summer & 1.0 & 2.7 & 1.7 & 1.7 & 0.5 & 0.1 \\
W5-Summer & 0.9 & 3.2 & 2.2 & 1.9 & 0.6 & 0.1 \\
W6-Summer & 0.7 & 3.9 & 3.2 & 2.2 & 0.7 & 0.2 \\
\hline
\end{tabular}


Table 2. Statistics of the seasonal wave periods for each point.

\begin{tabular}{ccccccc}
\hline \hline Season & Tmin & Tmax & range & mean & std & var \\
\hline W1-Fall & 3.2 & 15.7 & 12.5 & 8.3 & 2.5 & 4.9 \\
W2-Fall & 2.9 & 15.7 & 12.8 & 8.9 & 2.7 & 5.3 \\
W3-Fall & 3.1 & 16.1 & 13.0 & 9.6 & 2.6 & 5.0 \\
W4-Fall & 4.4 & 16.3 & 11.8 & 8.9 & 2.6 & 4.9 \\
W5-Fall & 4.2 & 16.3 & 12.2 & 7.4 & 1.9 & 2.4 \\
W6-Fall & 4.1 & 15.9 & 11.8 & 7.5 & 1.6 & 1.2 \\
\hline W1-Winter & 3.1 & 15.6 & 12.5 & 8.2 & 2.2 & 4.0 \\
W2-Winter & 3.1 & 16.2 & 13.1 & 8.7 & 2.3 & 4.4 \\
W3-Winter & 3.0 & 17.6 & 14.6 & 9.4 & 2.3 & 4.4 \\
W4-Winter & 4.0 & 17.4 & 13.4 & 8.7 & 2.1 & 3.5 \\
W5-Winter & 4.1 & 14.7 & 10.7 & 6.9 & 1.2 & 0.8 \\
W6-Winter & 4.3 & 16.0 & 11.6 & 7.5 & 1.1 & 0.5 \\
\hline W1-Spring & 3.1 & 14.5 & 11.4 & 7.6 & 1.9 & 2.9 \\
W2-Spring & 3.5 & 16.2 & 12.7 & 7.7 & 1.9 & 3.0 \\
W3-Spring & 4.1 & 17.7 & 13.7 & 8.0 & 2.3 & 4.7 \\
W4-Spring & 3.5 & 21.3 & 17.8 & 8.3 & 2.5 & 5.5 \\
W5-Spring & 3.7 & 21.4 & 17.7 & 7.8 & 2.7 & 6.4 \\
W6-Spring & 5.1 & 18.5 & 13.5 & 8.3 & 2.2 & 4.0 \\
\hline W1-Summer & 2.9 & 15.5 & 12.6 & 7.6 & 2.7 & 3.5 \\
W2-Summer & 3.1 & 16.5 & 13.4 & 7.8 & 2.8 & 4.0 \\
W3-Summer & 3.5 & 17.5 & 14.0 & 8.2 & 3.1 & 5.5 \\
W4-Summer & 4.2 & 19.4 & 15.2 & 8.8 & 3.6 & 6.4 \\
W5-Summer & 4.2 & 18.3 & 14.1 & 9.3 & 8.7 & 7.5 \\
W6-Summer & 4.1 & 16.5 & 12.3 & & & 3.6 \\
\hline
\end{tabular}

Table 3. Statistics of the seasonal wave directions for each point.

\begin{tabular}{ccc}
\hline \hline Season & mean & std \\
W1-Fall & 143 & 79 \\
W2-Fall & 151 & 58 \\
W3-Fall & 154 & 54 \\
W4-Fall & 130 & 51 \\
W5-Fall & 95 & 60 \\
W6-Fall & 61 & 43 \\
\hline W1-Winter & 130 & 81 \\
W2-Winter & 134 & 58 \\
W3-Winter & 139 & 50 \\
W4-Winter & 130 & 32 \\
W5-Winter & 115 & 18 \\
W6-Winter & 95 & 26 \\
\hline W1-Spring & 112 & 70 \\
W2-Spring & 121 & 54 \\
W3-Spring & 119 & 62 \\
W4-Spring & 130 & 68 \\
W5-Spring & 130 & 90 \\
W6-Spring & 93 & 82 \\
\hline W1-Summer & 117 & 70 \\
W2-Summer & 121 & 61 \\
W3-Summer & 120 & 67 \\
W4-Summer & 130 & 96 \\
W5-Summer & 142 & 141 \\
W6-Summer & 77 & 100 \\
\hline
\end{tabular}



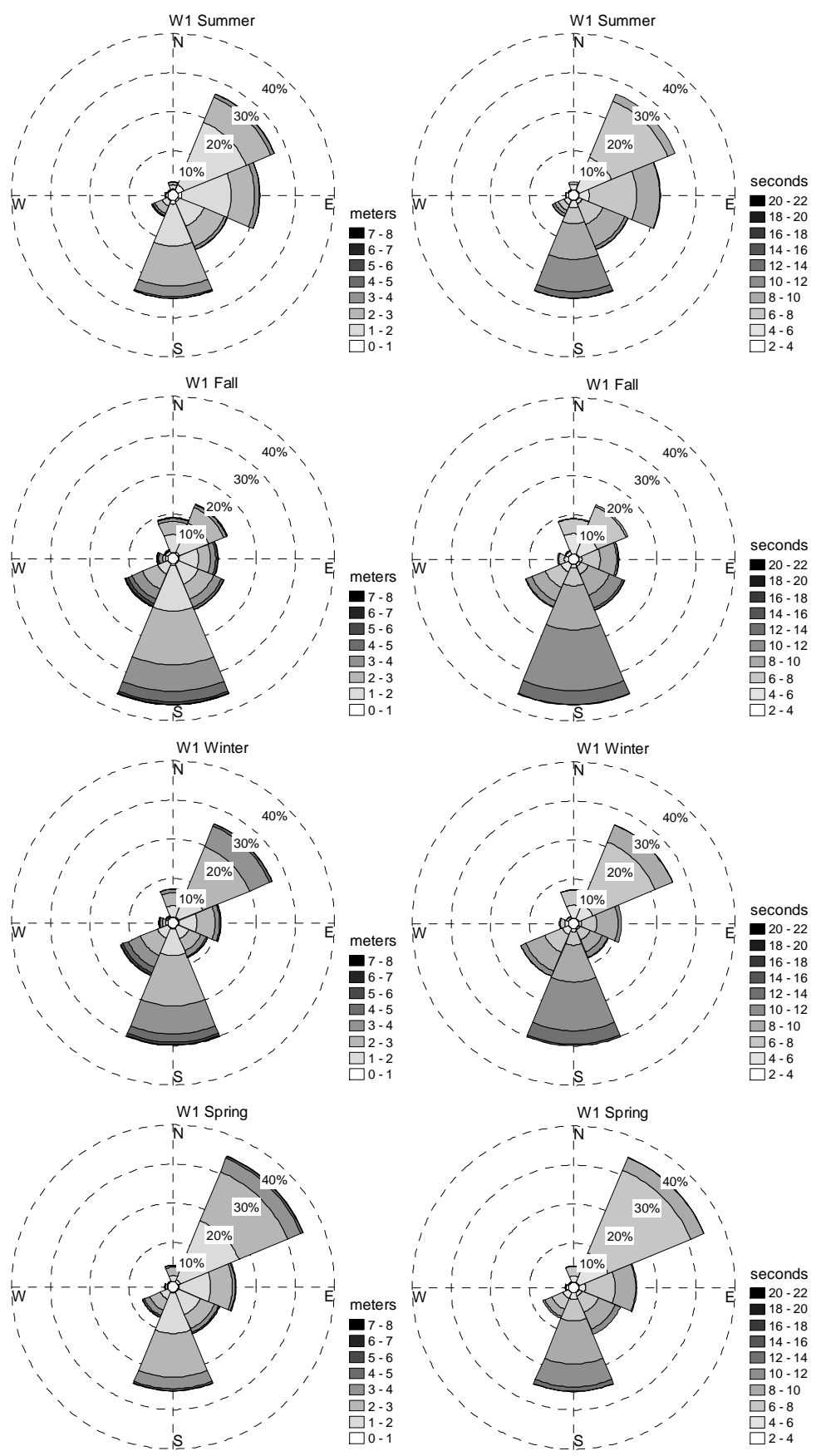

Fig. 4. Directional histograms of seasonal wave characteristics for W1. Left: wave height; Right: wave period. 

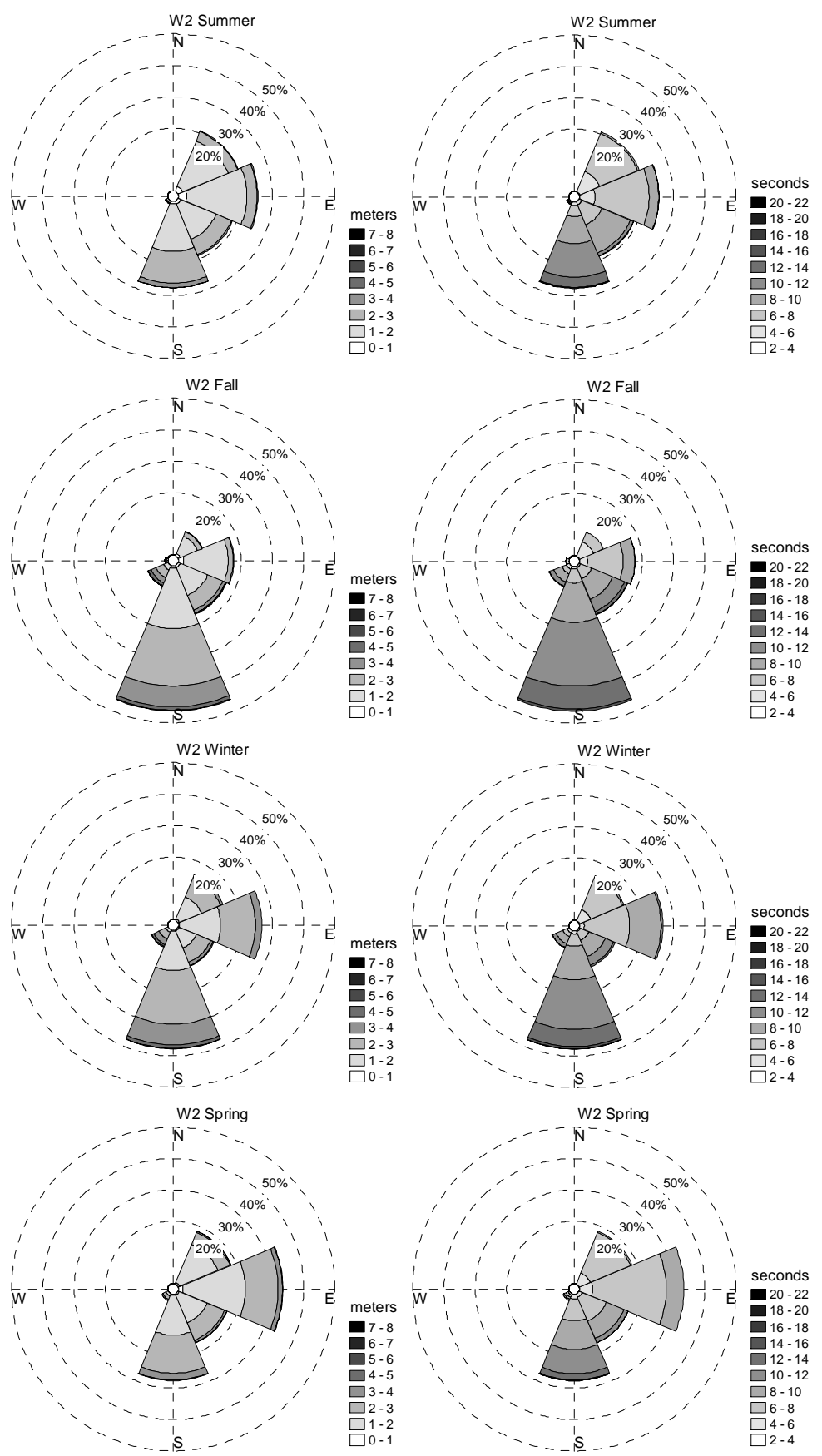

Fig. 5. Directional histograms of seasonal wave characteristics for W2. Left: wave height; Right: wave period. 

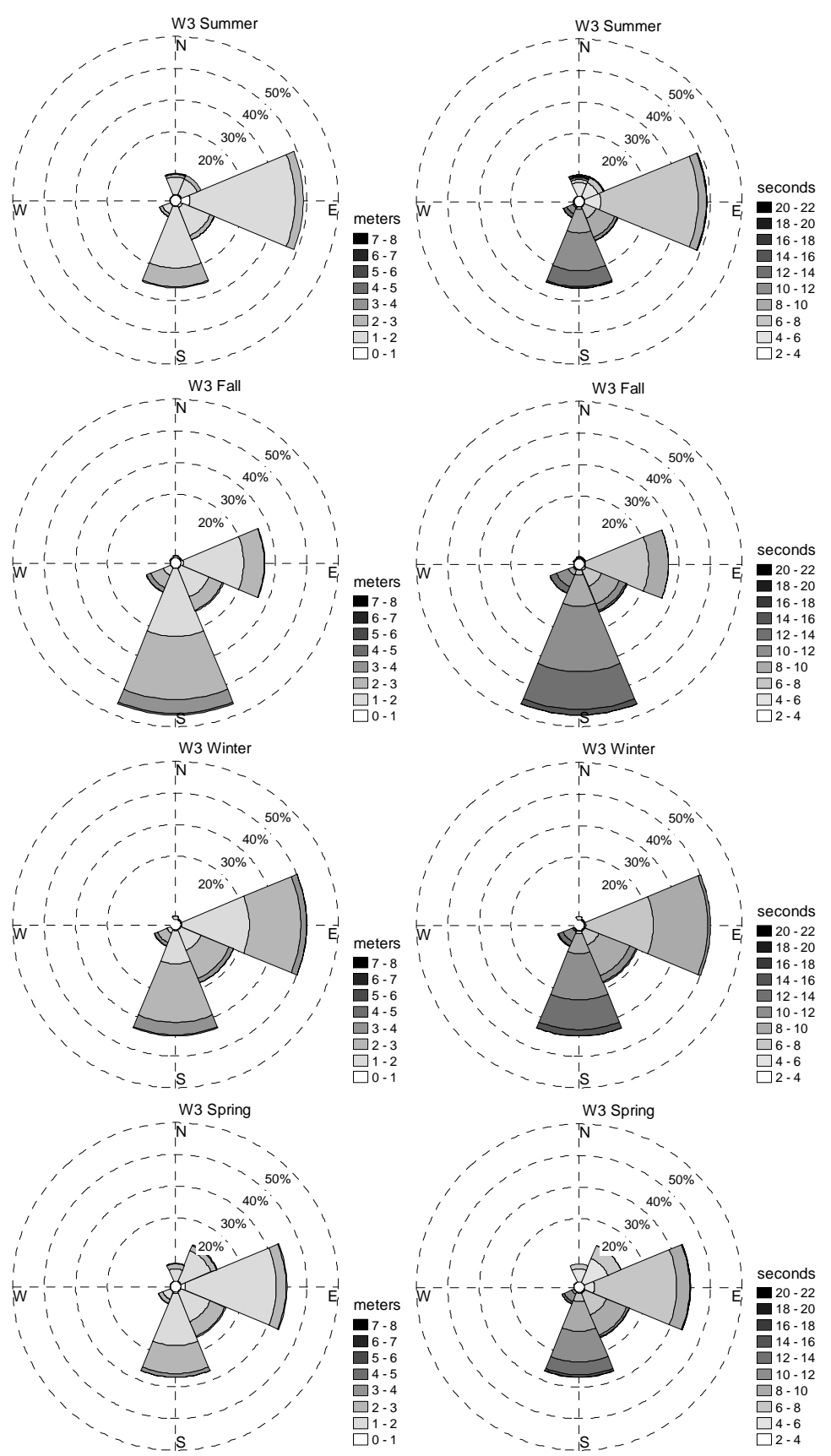

Fig. 6. Directional histograms of seasonal wave characteristics for W3. Left: wave height; Right: wave period. 

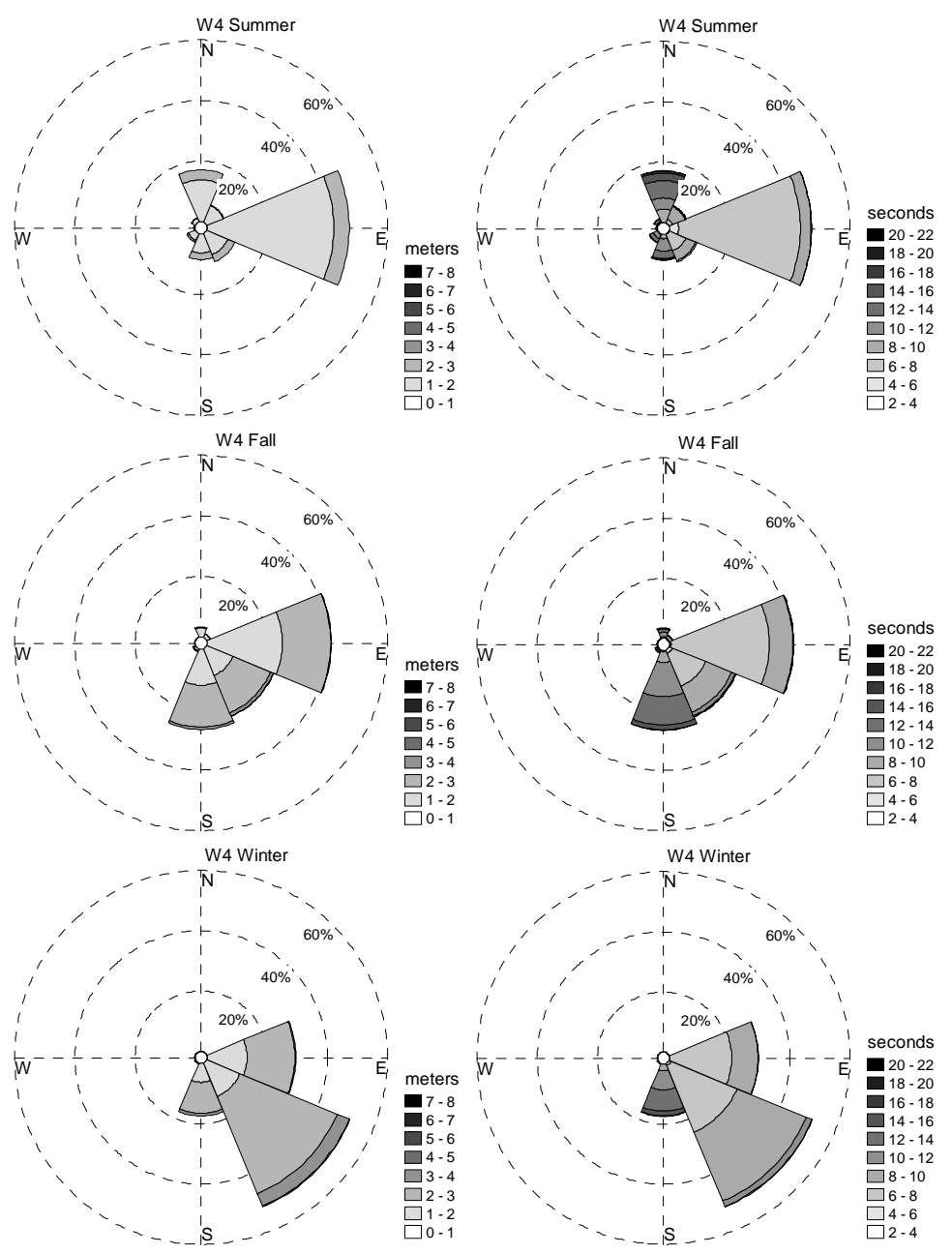

$\square 2-4$
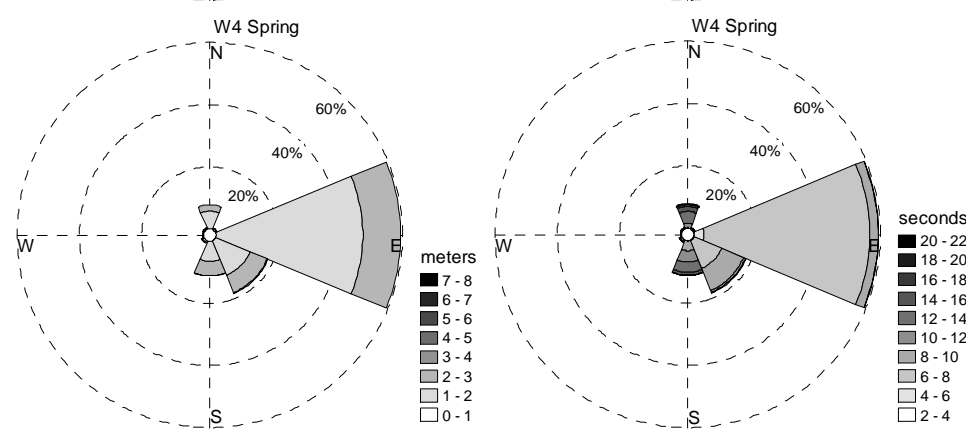

Fig. 7. Directional histograms of seasonal wave characteristics for W4. Left: wave height; Right: wave period. 

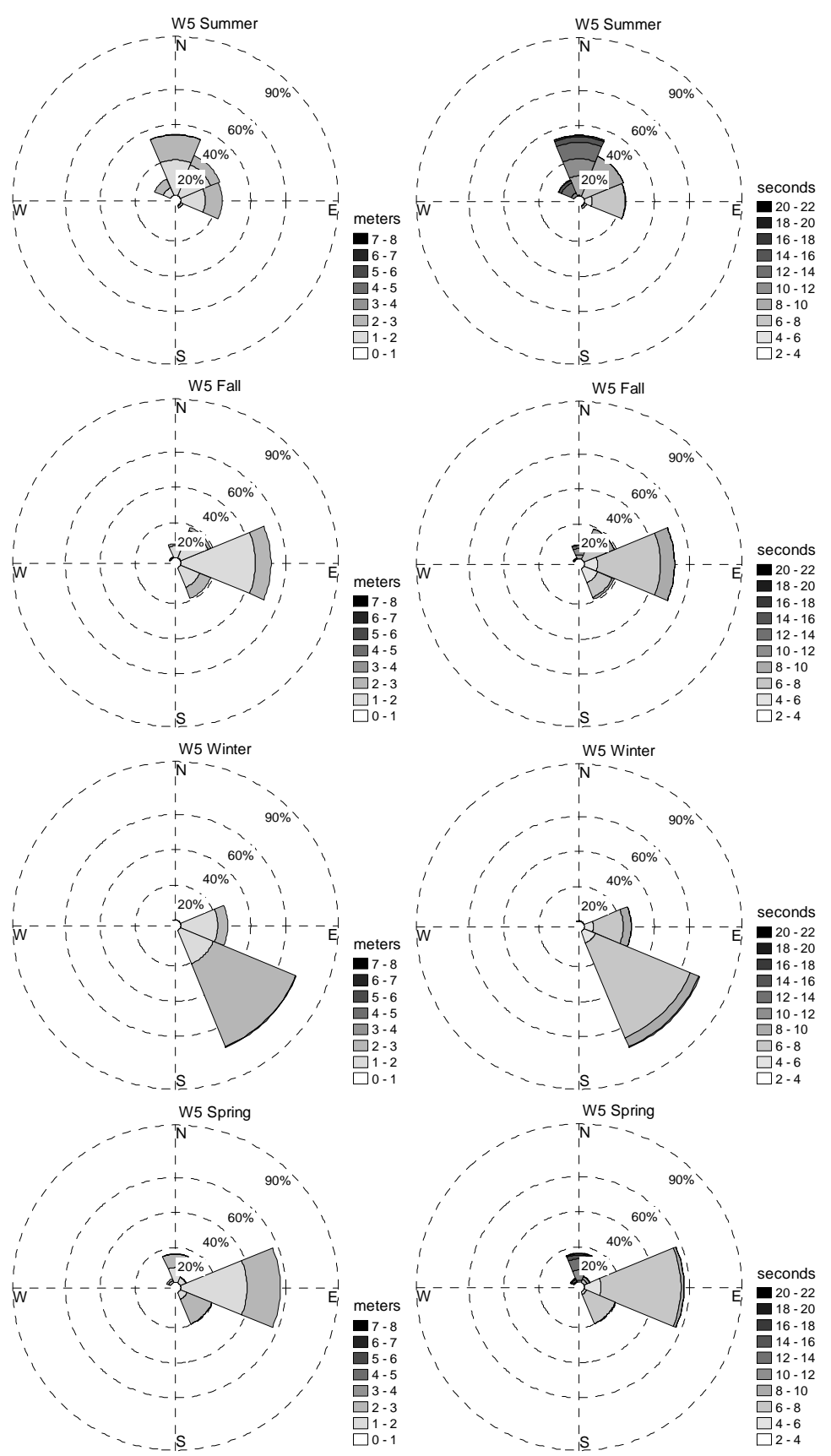

Fig. 8. Directional histograms of seasonal wave characteristics for W5. Left: wave height; Right: wave period. 

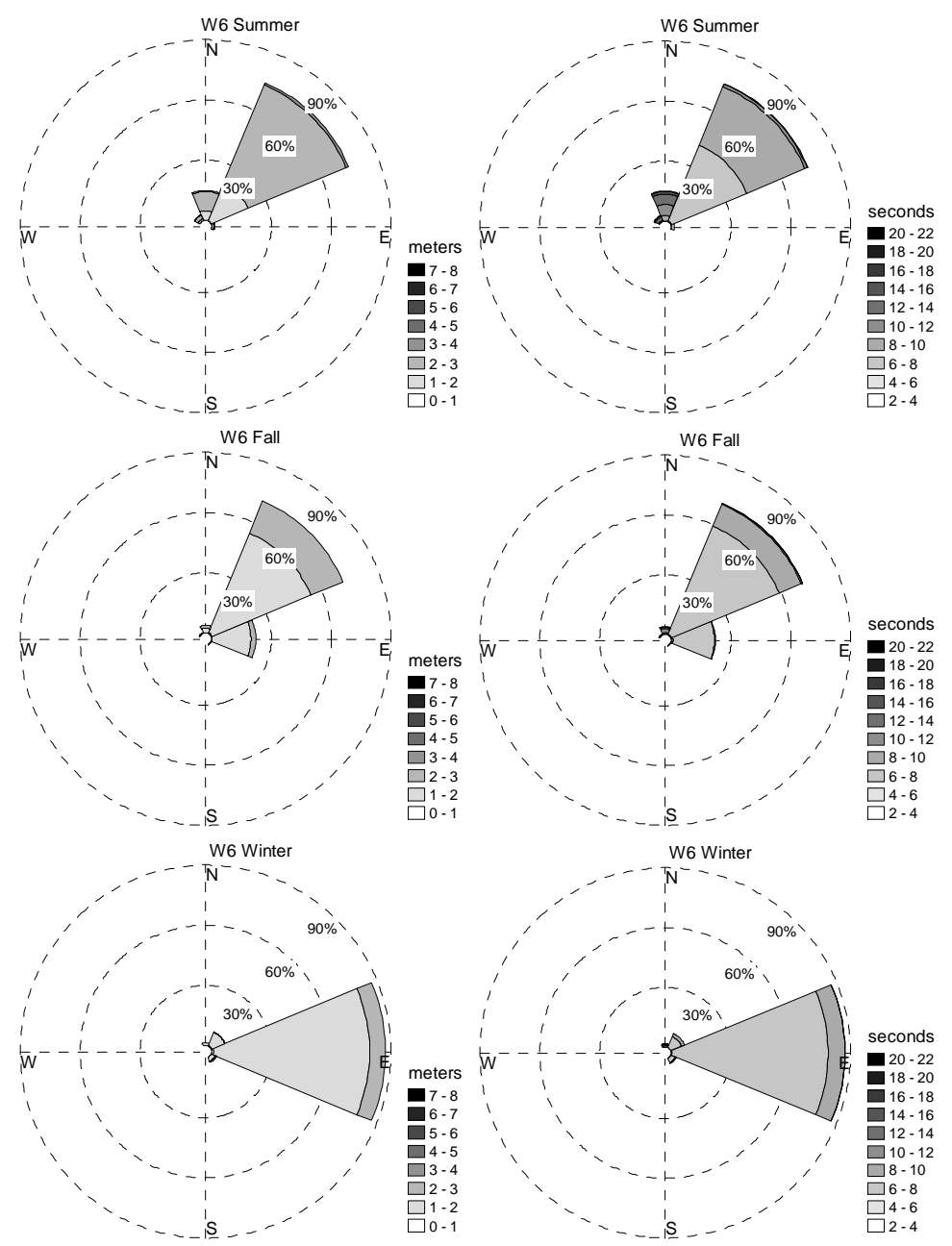

$\square 2-4$
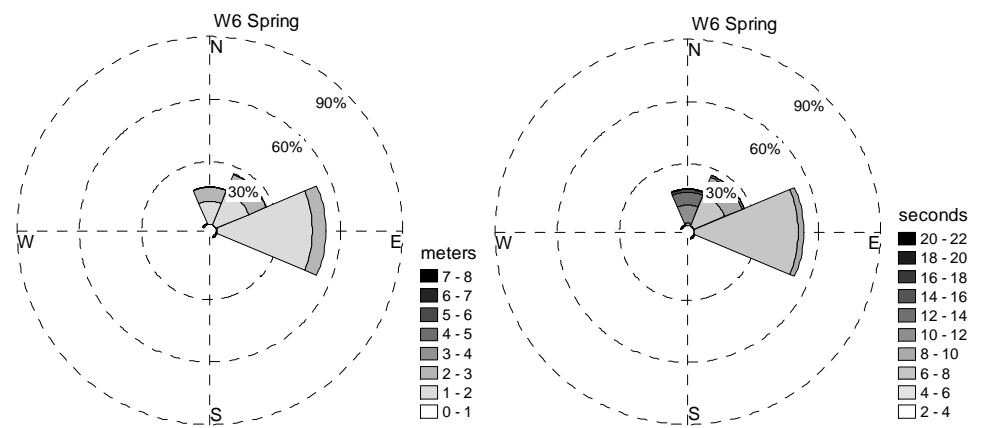

Fig. 9. Directional histograms of seasonal wave characteristics for W6. Left: wave height; Right: wave period.

\section{W1 - Southern Sector}

Summer:

Predominant wave directions are from NE (28.4\%) and from S (26.7\%);
Northeasterly waves present heights ranging between $1-2 \mathrm{~m}(18.4 \%)$ with periods of $6-8 \mathrm{~s}$ $(16.3 \%)$;

Southerly waves approach the region with heights between $1-2 \mathrm{~m}(11.4 \%)$ and $2-3 \mathrm{~m}(10.9 \%)$ 
with periods of $8-10 \mathrm{~s}(9.6 \%)$ and $10-12 \mathrm{~s}$ $(8.7 \%)$;

- $\quad$ Easterly waves (22.2\%) approach the region with dominant heights ranging between $1-2 \mathrm{~m}$ $(13.5 \%)$ and periods of $6-8 \mathrm{~s}(12.9 \%)$.

- Although occurring less frequently, southwesterly waves presented the peak in wave heights, reaching $5.9 \mathrm{~m}$.

Fall:

Dominant wave direction is from S (36.7\%), with heights between $2-3 \mathrm{~m}(14.1 \%)$ and periods of $10-12$ s $(15.9 \%)$.

- $\quad$ Highest waves are from S, reaching up to $7.3 \mathrm{~m}$, Winter: and the longest periods from SE, with $15 \mathrm{~s}$

- Dominant wave incidence direction is S (30.2\%), with heights ranging from $2-3 \mathrm{~m}(12.9 \%)$ with periods of $10-12 \mathrm{~s}(12.5 \%)$;

- $\quad$ Second in occurrence, are the northeasterly waves (26.4\%) with heights between $2-3 \mathrm{~m}(13 \%)$ and periods of $6-8 \mathrm{~s}(17.5 \%)$.

- Highest waves approach the region from the SW, reaching $6.9 \mathrm{~m}$.

Spring:

- $\quad$ Northeasterly waves are dominant during Spring (35.2\%), with heights ranging from $1-2 \mathrm{~m}$ $(16.4 \%)$ and $2-3 \mathrm{~m}(13.6 \%)$ and periods of $6-$ $8 \mathrm{~s}(23.1 \%)$

- The occurrence of waves from $\mathrm{S}$ is $25.5 \%$, with heights between $1-2 \mathrm{~m}(10.4 \%)$ and between 2 $3 \mathrm{~m}(11.4 \%)$ and periods of $8-10 \mathrm{~s}(11 \%)$.

- $\quad$ Highest waves are from NE, with $5.9 \mathrm{~m}$.

\section{W2 - Southeastern Sector}

Summer:

- Dominant wave direction is from S (29.2\%) with heights ranging between 1 and $2 \mathrm{~m}(16.1 \%)$ and periods of 10 to $12 \mathrm{~s}(11.3 \%)$.

- Waves from E occur during $27 \%$ of the summer months with heights between $1-2 \mathrm{~m}(20.4 \%)$ and periods of $6-8 \mathrm{~s}(18.3 \%)$.

- Waves from the northeast and southeast make similar contributions $(22.1 \%$ and $20.1 \%$, respectively) with heights between $1-2 \mathrm{~m}$ ( $16.7 \%$ and $12.9 \%$, respectively) and periods of 6 - $8 \mathrm{~s}(13.9 \%)$ and $8-10 \mathrm{~s}(10.4 \%)$, respectively.

- $\quad$ Highest waves are from SW, reaching up to $4 \mathrm{~m}$. Fall:

Dominant wave direction is from $\mathrm{S}(47.2 \%)$ with heights between $1-2 \mathrm{~m}(19.6 \%)$ and $2-3 \mathrm{~m}$ $(18.7 \%)$ and periods of $10-12 \mathrm{~s}(20.7 \%)$.

- Highest waves are from the southwest, reaching up to $6.3 \mathrm{~m}$.

Winter:

- Southern waves are dominant $(38.1 \%)$ with heights ranging between $2-3 \mathrm{~m}(17.1 \%)$ and periods of $10-12 \mathrm{~s}(16 \%)$.
Waves from $\mathrm{E}$ contribute with $27 \%$ with heights between $1-2 \mathrm{~m}(13.3 \%)$ and $2-3 \mathrm{~m}(11.3 \%)$ and periods of 6 - $8 \mathrm{~s}(14.7 \%)$. Spring:

Highest waves are from $\mathrm{S}$, reaching up to $5.7 \mathrm{~m}$.

Dominant direction is E $(33.7 \%)$ with heights between $1-2 \mathrm{~m}(20.1 \%)$ and periods of $6-8 \mathrm{~s}$ $(23.8 \%)$.

- Waves approaching the region from S (27.9\%) present heights between $1-2 \mathrm{~m}(12.9 \%)$ and 2 $3 \mathrm{~m}(12.3 \%)$ and periods of $8-10 \mathrm{~s}(9.2 \%)$ and 10 - 12 s $(7.8 \%)$.

Highest waves reach the region with up to $4.5 \mathrm{~m}$, from SE.

\section{W3 - Central Sector}

Summer:

- Dominant wave direction is E (41.3\%), with heights between $1-2 \mathrm{~m}(35.5 \%)$ and periods of 6 $-8 \mathrm{~s}(32.8 \%)$.

- $\quad$ Southern waves $(27.4 \%)$ present heights between $1-2 \mathrm{~m}(20.6 \%)$ and periods of $10-12 \mathrm{~s}$ $(12.7 \%)$.

Highest observed waves are from N, with $4.3 \mathrm{~m}$. Fall:

Southern waves are dominant $(47.3 \%)$ with heights between $1-2 \mathrm{~m}(21.8 \%)$ and $2-3 \mathrm{~m}$ (20.4\%) with periods ranging between $10-12 \mathrm{~s}$ $(21.1 \%)$.

- Waves from East $(27.3 \%)$ approach this sector with heights between $1-2 \mathrm{~m}(19.6 \%)$ and periods between $6-8 \mathrm{~s}(20.5 \%)$.

Highest waves are from SW with $4.4 \mathrm{~m}$ Winter:

- Dominant direction is from E (40.5\%) with heights from $1-2 \mathrm{~m}(21.6 \%)$ and $2-3 \mathrm{~m}$ $(16.6 \%)$ and periods between $6-8 \mathrm{~s}(21.5 \%)$ and $8-10$ s $(17.4 \%)$

- $\quad$ Southern waves $(33.9 \%)$ reach the region with heights of $2-3 \mathrm{~m}(18.7 \%)$ and periods of $10-$ $12 \mathrm{~s}(14.7 \%)$

Highest waves are from SW, with $4.9 \mathrm{~m}$ Spring:

- Dominant direction is E $(34.1 \%)$ with heights ranging from $1-2 \mathrm{~m}(29.2 \%)$ and periods of $6-$ $8 \mathrm{~s}(26.4 \%)$

- Waves from S (27.2\%) approach with heights of $1-2 \mathrm{~m}(16.4 \%)$ and periods between $8-10 \mathrm{~s}$ $(9.4 \%)$ and $10-12 \mathrm{~s}(9.8 \%)$.

- $\quad$ Highest waves are from S, with $4 \mathrm{~m}$.

\section{W4 - Eastern Sector}

Summer:

Dominant wave direction is from $\mathrm{E}(50.2 \%)$, with heights ranging between $1-2 \mathrm{~m}(44.6 \%)$ and periods of $6-8 \mathrm{~s}(43 \%)$; 
- The highest waves observed are from $\mathrm{N}$, with Fall: $2.6 \mathrm{~m}$, and the longest periods from $\mathrm{N}$, with $19 \mathrm{~s}$.

- Dominant wave directions are from E (42.1\%), S (27.1\%) and SE (24.6\%);

- $\quad$ Easterly waves present heights between $1-2 \mathrm{~m}$ $(25.4 \%)$ and $2-3 \mathrm{~m}(16.5 \%)$ and periods of $6-$ 8 s $(33.2 \%)$;

- $\quad$ Southerly waves approach the region with heights between $1-2 \mathrm{~m}(12.2 \%)$ and $2-3 \mathrm{~m}(14.1 \%)$ and periods between $10-12 \mathrm{~s}(11.6 \%)$ and $12-$ 14 s $(9.5 \%)$;

- South-easterly waves have typical heights ranging between $1-2 \mathrm{~m}(9.7 \%)$ and $2-3 \mathrm{~m}$ $(13.8 \%)$ and periods between $6-8 \mathrm{~s}(12.1 \%)$ and $8-10$ s $(9.5 \%)$

- The highest waves observed are from SE, of $4 \mathrm{~m}$, and the longest periods from $\mathrm{S}$, reaching $16 \mathrm{~s}$.

Winter:

- Dominant wave directions are from SE (52.2\%) and $\mathrm{E}(29.8 \%)$;

- $\quad$ Southeasterly waves have typical heights ranging between $2-3 \mathrm{~m}(35.5 \%)$ and periods between 6 $-8 \mathrm{~s}(24.1 \%)$ and $8-10 \mathrm{~s}(25 \%)$;

- Easterly waves present heights between $1-2 \mathrm{~m}$ $(13.1 \%)$ and $2-3 \mathrm{~m}(16.2 \%)$ and periods of $6-$ 8 s $(20.6 \%)$

- The highest waves observed are from SE, with $4.3 \mathrm{~m}$, and the longest periods from $\mathrm{S}$, with $17 \mathrm{~s}$. Spring:

Dominant wave direction is from $\mathrm{E}(60.1 \%)$, with heights between $1-2 \mathrm{~m}(47.6 \%)$ and periods of 6 $-8 \mathrm{~s}(53.8 \%)$;

- The highest waves observed are from SE, with $3.8 \mathrm{~m}$, and the longest periods from $\mathrm{N}$, with $21 \mathrm{~s}$.

\section{W5 -Northeastern Sector}

Summer:

- Dominant wave directions are from N $(36.5 \%)$, NE (26\%) and E (25\%);

- Northerly waves approach the region with heights between $1-2 \mathrm{~m}(21.3 \%)$ and $2-3 \mathrm{~m}(15.3 \%)$ and periods ranging between $8-10 \mathrm{~s}(11.7 \%), 10$ -12 s $(10.4 \%)$ and $12-14$ s $(9.9 \%)$;

- $\quad$ Northeasterly waves have typical heights between $1-2 \mathrm{~m}(20 \%)$ and periods between $6-8 \mathrm{~s}$ $(15.3 \%)$ and $8-10 \mathrm{~s}(10.7 \%)$;

- Easterly waves present heights between $1-2 \mathrm{~m}$ $(14.7 \%)$ and $2-3 \mathrm{~m}(10.3 \%)$ and periods of $6-$ 8 s $(20 \%)$;

- $\quad$ The highest waves observed are from N, with 3.1 Fall: $\mathrm{m}$, and the longest periods from $\mathrm{N}$, with $18 \mathrm{~s}$.

Dominant wave direction is from E (52.7\%), with heights of $1-2 \mathrm{~m}(43.4 \%)$ and periods of $6-8 \mathrm{~s}$ $(36.9 \%)$;
The highest waves observed are from SE, with $2.8 \mathrm{~m}$, and the longest periods from $\mathrm{N}$, with $16 \mathrm{~s}$.

Winter:

- Dominant wave direction is from SE (72.6\%), with heights of $2-3 \mathrm{~m}(51.6 \%)$ and periods of 6 $-8 \mathrm{~s}(59.3 \%)$;

- The highest waves observed are from SE, being of $3.4 \mathrm{~m}$, and the longest periods from $\mathrm{N}$, of $14 \mathrm{~s}$. Spring:

Dominant wave direction is from E (57.5\%), with heights between $1-2 \mathrm{~m}(37.9 \%)$ and $2-3 \mathrm{~m}$ (19.3\%) and periods of $6-8 \mathrm{~s}(46.1 \%)$;

- The highest waves observed are from SE, with $3.2 \mathrm{~m}$, and the longest periods from $\mathrm{N}$, with $21 \mathrm{~s}$.

\section{W6 - Northern Sector}

Summer:

- Dominant wave direction is from NE (79.1\%), with heights of $2-3 \mathrm{~m}(56.7 \%)$ and periods between $6-8 \mathrm{~s}(43.4 \%)$ and $8-10 \mathrm{~s}(33.6 \%)$;

- $\quad$ The highest waves observed are from NE, of 3.8 $\mathrm{m}$, and the longest periods from $\mathrm{N}$, with $16 \mathrm{~s}$. Fall:

- Dominant wave direction is from NE (73\%), with heights of $1-2 \mathrm{~m}(54.8 \%)$ and periods of $6-8 \mathrm{~s}$ $(60 \%)$;

- The highest waves observed are from NE, reaching $3 \mathrm{~m}$, and the longest periods from $\mathrm{N}$, with $15 \mathrm{~s}$.

Winter:

Dominant wave direction is from E (88.1\%), with heights of $1-2 \mathrm{~m}(79.1 \%)$ and periods of $6-8 \mathrm{~s}$ $(79.1 \%)$;

- $\quad$ The highest waves observed are from SE, of 2.6 $\mathrm{m}$, and the longest periods from $\mathrm{N}$, with $16 \mathrm{~s}$.

Spring:

- Dominant wave direction is from E (53.6\%), with heights of $1-2 \mathrm{~m}(46.4 \%)$ and periods of $6-8 \mathrm{~s}$ $(50.5 \%)$;

- The highest waves observed are from NE, reaching $3.4 \mathrm{~m}$, and the longest periods from $\mathrm{N}$, with $18 \mathrm{~s}$.

\section{Modal Height-Period Combination and Monthly Variations}

The distribution of wave height and period, plotted jointly in Fig. 10 for each sector, emphasizes the difference in wave characteristics along the Brazilian coast. In sectors W1 and W2, the modal height-period combination is for waves with heights ranging from 1.5 to $3.0 \mathrm{~m}$ and periods of 6 to $8 \mathrm{~s}$. W3 and W4 modal wave combination is for waves with similar periods (6 to $8 \mathrm{~s}$ ) but lower wave heights, between 1.0 and $2.0 \mathrm{~m}$. In sectors W5 and W6, waves present less variability, being concentrated mainly in the height range of 1.5 to $2.0 \mathrm{~m}$ and periods of 6 to $8 \mathrm{~s}$. This low variability in wave characteristics in W5 and 
W6 is shown by the well-defined peaks in the contours of the histogram (Fig. 10).

In order to establish the daily variations in wave characteristics along the Brazilian coast, the synergy of wave height and period, wave power, was calculated for each sector through the application of Eq. 1. Figure 11 shows the daily averaged variations for the eleven-year time series of wave power that reach each of the six studied sectors. The northward decrease in wave power is clearly seen from $\mathrm{W} 1$ to $\mathrm{W} 6$, with $\mathrm{W} 1$ to $\mathrm{W} 4$ presenting similar variation patterns, with higher wave energy during the southern hemisphere's fall, winter and spring months, while in W5 and W6 the summer months are the most energetic. Again, the lower variability in wave characteristics in W5 and W6, in contrast with that of the other coastal sectors, can be seen, with its much smaller range in wave power (Fig. 11).

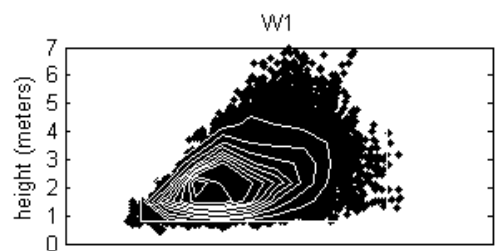

W3

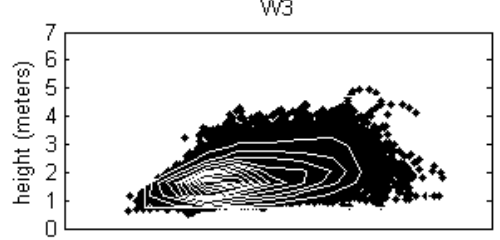

W5

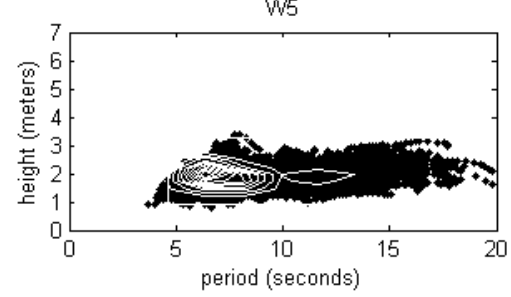

W2

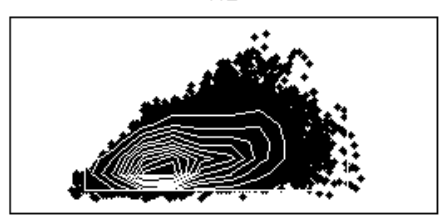

W4

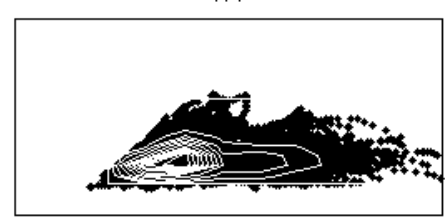

WG

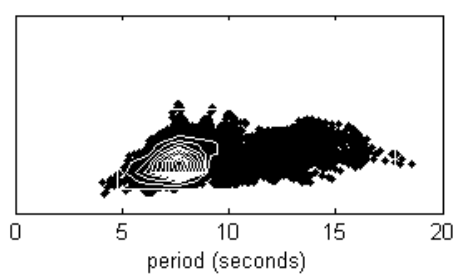

Fig. $\quad 10 . \quad$ Combined distribution of significant wave height and peak period with percentage of occurrence contours. Contours are given in intervals of $1 \%$ (e.g. for W1 the external contour is $1 \%$ of occurrence and the inner contour represents $8 \%$ of occurrence).

Fig. 11. Daily variations in wave power $P$ as obtained from Eq. 1 based on the eleven-year database for each sector of the Brazilian coast.
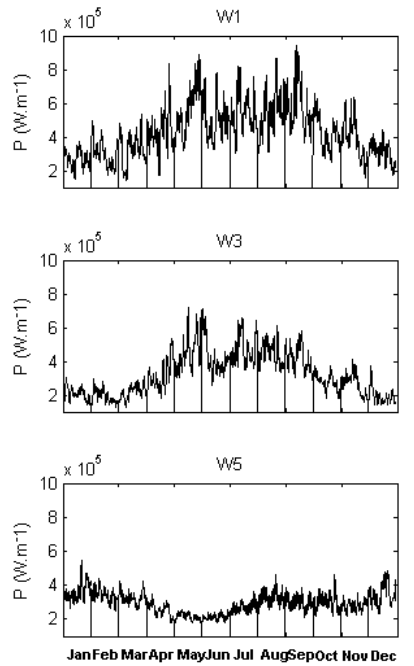

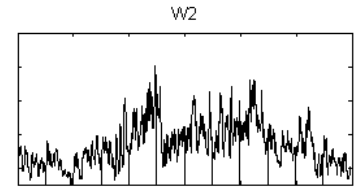

W4

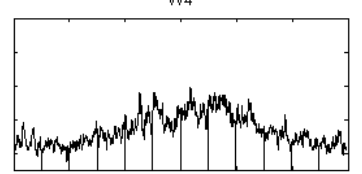

WE

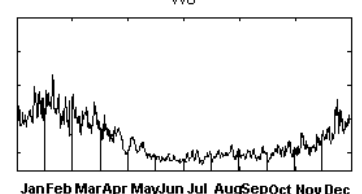




\section{Discussion ANd Conclusions}

Based on the available archive of hindcast wave simulations with NWW3 (NCEP/NOAA), we defined the wave climate off the Brazilian coast. With only limited records of wave data available for the region, these data become important background information for a range of applications on the Brazilian coast. The data have been validated for the southern region by comparing them with those recorded by Araújo et al. (2003). Since there is a difference in the position between measurements and the extracted modeled waves, the comparison is qualitative only, but provides an insight into the general wave climate given by each method. In general, the wave climate is similar in the comparison, with directions being better represented during fall, spring and winter periods than during the summer. The frequency of higher wave classes is greater in the modeled waves, which agrees with the findings of Tolman et al. (2002).

From the six points defined here for the wave analysis undertaken along the Brazilian shelfbreak, a clear trend in wind-generated wave energy, decreasing from south (W1) to north (W6), may be seen. This is clearly the result of the influence of the strong winds associated with the passage of cold fronts which most affect the southern part of Brazil, losing energy while propagating northwards. The large scale atmospheric system of southern Brazil is controlled by seasonal oscillations of the intensity and position of the South Atlantic High (SAH) (ORSELLI, 1986; CASTRO; MIRANDA, 1998) and the passage of polar front systems at intervals ranging between 6 and 10 days (STECH, 1990; STECH; LORENZZETTI, 1992). Winds associated with the passage of cold fronts are usually more intense during the fall and winter months due to the higher frequency of cyclogenesis (NIMER, 1989; GAN; RAO, 1991), also being reflected in the higher frequency of high wave energy events (Table 4). Moving northwards, the frequency and intensity of high wave energy events is gradually reduced, with only $\mathrm{W} 1$ and $\mathrm{W} 2$ presenting waves of more than $6 \mathrm{~m}$ (Table 4). The influence of waves generated by the strong winds that occur during the passage of cold fronts can be seen up to the northeast of Brazil (W4) during winter months, although much less energetic. In the central sector (represented by W3), the main atmospheric circulation is determined by the South Atlantic anti-cyclone cell with only slight seasonal variations (DOMINGUEZ et al., 2009), although the waves generated due to the advance of polar fronts result in more energetic conditions during the winter months.

Table 4. Number of yearly occurrence of events with wave heights above 2.0, 3.0, 4.0, 5.0, 6.0 and $7.0 \mathrm{~m}$ by season for each sector.

\begin{tabular}{|c|c|c|c|c|c|c|c|}
\hline & Season & $>2 \mathrm{~m}$ & $>3 m$ & $>4 \mathrm{~m}$ & $>5 \mathrm{~m}$ & $>6 \mathrm{~m}$ & $>7 \mathrm{~m}$ \\
\hline \multirow[t]{5}{*}{ W1 } & summer & 12.18 & 4.45 & 1.00 & 0.18 & & \\
\hline & fall & 16.09 & 11.18 & 5.64 & 1.91 & 0.64 & 0.18 \\
\hline & winter & 16.36 & 13.27 & 5.82 & 1.73 & 0.55 & \\
\hline & spring & 16.82 & 8.82 & 2.55 & 0.73 & & \\
\hline & total & 61.45 & 37.73 & 15.00 & 4.55 & 1.18 & 0.18 \\
\hline \multirow[t]{5}{*}{ W2 } & summer & 10.45 & 1.91 & 0.09 & & & \\
\hline & fall & 14.27 & 7.00 & 2.36 & 0.55 & 0.09 & \\
\hline & winter & 15.73 & 7.73 & 2.18 & 0.45 & & \\
\hline & spring & 14.36 & 3.64 & 0.45 & & & \\
\hline & total & 54.82 & 20.27 & 5.09 & 1.00 & 0.09 & \\
\hline \multirow[t]{5}{*}{ W3 } & summer & 5.91 & 0.55 & & & & \\
\hline & fall & 13.55 & 4.73 & 0.45 & & & \\
\hline & winter & 16.64 & 4.91 & 0.55 & & & \\
\hline & spring & 9.64 & 1.45 & & & & \\
\hline & total & 45.73 & 11.64 & 1.00 & & & \\
\hline \multirow[t]{5}{*}{ W4 } & summer & 6.36 & & & & & \\
\hline & fall & 13.45 & 1.09 & & & & \\
\hline & winter & 16.09 & 2.91 & 0.18 & & & \\
\hline & spring & 9.18 & 0.09 & & & & \\
\hline & total & 45.09 & 4.09 & 0.18 & & & \\
\hline \multirow[t]{5}{*}{ W5 } & summer & 10.82 & 0.09 & & & & \\
\hline & fall & 8.73 & & & & & \\
\hline & winter & 8.91 & 0.55 & & & & \\
\hline & spring & 10.91 & 0.18 & & & & \\
\hline & total & 39.36 & 0.82 & & & & \\
\hline \multirow[t]{5}{*}{ W6 } & summer & 14.82 & 1.73 & & & & \\
\hline & fall & 8.36 & & & & & \\
\hline & winter & 4.64 & & & & & \\
\hline & spring & 7.73 & 0.27 & & & & \\
\hline & total & 35.55 & 2.00 & & & & \\
\hline
\end{tabular}


The equatorial region of Brazil (W4, W5 and W6) has its atmospheric system determined by the Intertropical Convergence Zone (ITCZ), giving rise to northeasterly and southeasterly trade winds which converge over this region. The ITCZ migrates meridionally during the year, reaching farthest north in August-September and coming closest to the Equator in March-April, exerting a significant control of the rainfall and wind regimes (NIMER, 1979; McGREGOR; NIEUWOLT, 1998). W5 showed wave directions predominantly from $\mathrm{E}$ and $\mathrm{SE}$, and W6 from $\mathrm{E}$ and NE, showing a very clear signal throughout the seasons, both being highly influenced by the trade winds, with its variation being attributed to the seasonal migration of the ITCZ. W4 presented waves, mainly from E/SE, at this latitude generated mainly by trade winds, though during the fall and winter, waves from the $\mathrm{S}$ are also noticeably present, showing that cold fronts can affect the wave climate of this sector too.

In this paper we present a general overview of the wave climate off the Brazilian coast based on data extracted from the NWW3 model in the attempt to overcome the lack of wave data along the Brazilian coast. The data presented provide a first assessment of the wave climate for Brazilian waters and regional aspects of wave climate distribution can be further assessed with the analysis at higher spatial resolution and wave transformation processes as they propagate over the shallower waters of the continental shelf.

\section{ACKNOWLEDGEMENTS}

The authors would like to thank the Oceanographic Institute of the University of São Paulo (IOUSP), and the State of São Paulo's Research Foundation (FAPESP). We are also thankful for the reviewers' helpful comments, which contributed to the improvement of the manuscript. E.S. is sponsored by a CNPq fellowship (ref. $n^{\circ}$. 305805/2009-6).

\section{REFERENCES}

ARAÚJO, C. E. S.; FRANCO, D.; MELO, E.; PIMENTA, F. Wave regime characteristics of southern Brazilian Coast. In: INTERNATIONAL CONFERENCE ON COASTAL AND PORT ENGINEERING IN DEVELOPING COUNTRIES, 6., 2003, Colombo, Sri Lanka. Proceedings... COPEDEC VI, 2003. v. 97, p. 15.

BENSI, M.; MARINHO, R. A.; MAIA, L. P. Clima de ondas e sua implicação com a erosão costeira ao longo do Estado do Ceará. In: CONGRESSO DE ENGENHARIA DE PESCA, Fortaleza, Ceará, 2005. CONBEP, 2005. p. 802-815.

BITTENCOURT, A. C. S. P; DOMINGUEZ, J. M. L; FONTES, L. C. S.; SOUSA, D. L.; SILVA, I. R.;
SILVA, F. R. Wave refraction, river damming, and episodes of severe shoreline erosion: The São Francisco river mouth, Northeastern Brazil. J. coast. Res., v. 23, n. 4, p. 930-938, 2007.

CAIRES, S.; STERL, A.; BIDLOT, J. R.; GRAHAM, N.; SWAIL, V. Intercomparison of different wind-wave reanalyses. J. Climate, v. 17, p. 1893-1913, 2004.

CANDELLA, R. N. Estudo de casos de ondas no Oceano Atlântico Sul através de modelagem numérica. Master's Thesis, Universidade Federal do Rio de Janeiro - UFRJ, Brazil, 1997. 80 p.

CAPLAN, P. ; DERBER, J. ; GEMMILL,W. ; HONG, S. Y.; PAN, H. L. ; PARISH, D. F. Changes to the 1995 NCEP operational medium-range forecast model analysis/forecast system. Weather Forecasting, v. 12, p. 581-594, 1997.

CASTRO, B. M ; MIRANDA L. B. Physical Oceanography of the Western Atlantic Continental Shelf located between $4^{\circ} \mathrm{N}$ and $34^{\circ} \mathrm{S}$ - Coastal segment $(4, \mathrm{~W})$. In: ROBINSON A. R.; BRINK K. H. (Ed.). The Sea. New York: J. Wiley \& Sons, 1998. v. 11, p. 209-251.

CHERFAS, C. The fringe of the ocean - under siege from land. Science, v. 248, n. 4952, p. 163-164, 1990.

DERBER, J. C.; PARISH, D. F.; LORD, S. J. The new global operational analysis system at the National Meteorological Center. Weather Forecasting, v. 6, p. 538-547, 1991.

DOMINGUEZ, J. M. L. The coastal zone of Brazil. In: DILLENBURG, S.R.; HESP, P.A. (Ed.). Geology and Geomorphology of Holocene coastal barriers of Brazil. Berlin: Springer, 2009. p. 17-51. (Lecture Notes in Earth Sciences, v. 107, 2009).

DOMINGUEZ, J. M. L.; ANDRADE, A. C. S.; ALMEIDA, A. B.; BITTENCOURT, A. C. S. P. The Holocene Barrier Strandplains of the State of Bahia. In: DILLENBURG, S.R.; HESP, P.A. (Ed.). Geology and Geomorphology of Holocene coastal barriers of Brazil. Berlin: Springer, 2009. p. 253-288. (Lecture Notes in Earth Sciences, v. 107, 2009).

GAN, M. A.; RAO, V. B. Surface cyclogenesis over South America. American Meteorological Society, 1991. v. 119, p. 1293-1302.

GRAHAM, N. E.; DIAZ, H. F. Evidence for intensification of North Pacific winter cyclones since 1948. Bull. Am. Met. Soc., v. 82, p. 1869-1893, 2001.

INMAN, D. L.; MASTERS, P. M. Status of research on the nearshore. Shore Beach, v. 62: 11-20, 1994.

KANAMITSU, M. Description of the NMC global data assimilation and forecast system. Weather Forecasting, v. 4, p. 335-243, 1989.

KANAMITSU, M.; ALPERT, J.; CAMPANA, K.; CAPLAN, P.; DEAVEN, D.; IREDELL, M.; KATZ, B.; PAN, H. L.; SELA, J.; WHITE, G. Recent Changes implemented into the Global Forecast System at NMC. Weather Forecasting, v. 6, p. 425-435, 1991.

KOMAR, P. D. Beach processes and sedimentation. 2nd ed. Upper Saddle River, N.J.: Prentice Hall, 1998. 544 p.

McGREGOR, G. R.; NIEUWOLT, S. Tropical Climatology. $2^{\text {nd }}$ ed. New York: John Wiley and Sons, $1998.339 \mathrm{p}$.

NIMER, E. Climatologia do Brasil. Rio de Janeiro: IBGE, 1979. 422p. (Série Recursos Naturais e Meio Ambiente, v. 4). 
NIMER, E. Climatologia do Brasil. $2^{\text {nd }}$ ed. Rio de Janeiro: IBGE, 1989. 421p.

ORSELLI, J. Climatologia. In: GAPLAN-SC. Atlas de Santa Catarina, 1986. p. 38-39.

PEREIRA, J.; CANDELLA, R. N.; CARVALHO, J. L. B. O clima de ondas na costa sul de Arraial do Cabo, RJ: distribuição de parâmetros de onda. Notas Tec. Facimar, v. 4, p. 1-9, 2000.

RUSU, L.; PILAR, P.; GUEDES SOARES; C. Hindcast of the wave conditions along the west Iberian coast. Coast. Engng, v. 55, n. 11, p. 906-919, 2008.

SEBASTIÂO, P.; GUEDES SOARES, C.; BOOIJ, N. Wave hindcasting off the coast of Portugal. Coast. Engng, v. 40, n. 4, p. 411-425, 2000.

SIEGLE, E.; ASP, N. E. Wave refraction and longshore transport patterns along the southern Santa Catarina coast. Braz. J. Oceanogr., v. 55, p. 109-120, 2007.

SIEGLE, E.; HUNTLEY, D. A.; DAVIDSON, M. A. Coupling video imaging and numerical modeling for the study of inlet morphodynamics. Mar. Geology, v. 236, p. 143-163, 2007.

SIEGLE, E.; HUNTlEY, D. A.; DAVIDSON, M. A. Physical controls on the dynamics of inlet sandbar systems. Ocean Dynamics, v. 54, p. 360-373, 2004.

STECH, J. L. Um estudo comparativo da dinâmica da circulação de inverno entre as plataformas continentais das costas sudeste do Brasil e dos Estados Unidos utilizando um modelo numérico. Tese (Doutorado). Universidade de São Paulo, São Paulo, 1990.
STECH, J. L.; LORENZZETTI, J. A. Response of the South Brazil Bight to the passage of Wintertime cold fronts. J. geophys. Res., v. 97(C6), p. 9507-9520,1992.

TOLMAN, H. L. User manual and system documentation of WAVEWATCH III version 1.18. NOAA/NWS/NCEP/OMB. Tech. Note 166, 1999. 110 p. [Available online at <http://polar.ncep.noaa.gov/waves/wavewatch.>.

TOLMAN, H. L. User manual and system documentation of WAVEWATCH-III version 1.15. NOAA / NWS / NCEP / OMB. Tech. Note, 1997. v.151, p. 97, 1997.

TOLMAN, H. L.Validation of a new global wave forecast system at NCEP. In: EDGE B. L.; HELMSLEY J.M. (Ed.). Ocean wave measurements and analysis, ASCE, 1998. p. $777-786$

TOLMAN, H. L.; BALASUBRAMANIYAN, B.; BURROUGHS, L.D.; CHALIKOV, D. V.; CHAO, Y. Y.; CHEN, H. S.; GERALD, V. M. Development and implementation of wind-generated ocean surfacewave models at NCEP. Washington, D.C.: American Meteorological Society, 2002. v.17, p. 311-333.

WANG, X. L. L.; SWAIL, V. R. Changes of extreme wave heights in Northern Hemisphere oceans and related atmospheric circulation regimes. J. Climate, v. 14, p. 2204-2221, 2001.

(Manuscript received 17 August 2009; revised 05 November 2009; accepted 14 December 2009) 